\title{
CHARACTER BUILDING PADA ANAK USIA DINI MELALUI METODE PARENTING DI LINGKUNGAN KELUARGA
}

\author{
Neng Sri Nuraeni \\ Universitas Islam Negeri (UIN) Syarif Hidayatullah Jakarta \\ nengsrinuraeni@uinjkt.ac.id
}

\begin{abstract}
Abstrak: Pendidikan sejak usia dini kepada anak-anak merupakan salah satu cara untuk membentuk karakter dan kepribadian anak untuk masa yang akan datang. Anak - anak yang memiliki kecerdasan yang baik biasanya akan memiliki karakter yang baik pula. Setiap orang tua pasti ingin anaknya kelak dapat berguna dan memiliki masa depan yang baik. Masa depan yang baik akan bisa tercapai jika anak diberikan pembelajaran tata krama dan juga kemandirian yang tepat. Kebiasaan - kebiasaan yang baik akan membantu anak - anak untuk bisa hidup dengan baik dan sehat. Anak anak sejak masa bayi hingga usia prasekolah memiliki lingkungan tunggal, yaitu keluarga. Oleh sebab itu tidak mengherankan jika dikatakan bahwa kebiasaan yang dimiliki anak - anak sebagian besar terbentuk oleh pendidikan dalam keluarga, sejak dari bangun tidur hingga saat tidur kembali, anak-anak menerima pengaruh dan pendidikan dari lingkungan terutama keluarga. Sehingga pendidikan dalam keluarga merupakan inti dan fondasi dari upaya pendidikan secara keseluruhan. Pendidikan dalam keluarga yang baik akan menjadi fondasi yang kokoh bagi upaya upaya pendidikan selanjutnya baik di sekolah maupun di luar sekolah. Berbagai macam cara akan dilakukan oleh orang tua untuk bisa membimbing anaknya ke arah yang baik. salah satu cara yang dapat dilakukan oleh orang tua dirumah adalah dengan menerapkan metode Parenting. Akhir-akhir ini munculnya istilah Parenting menjadi paradigma baru untuk para orang tua dalam mendidik anak serta menumbuhkan karakter pada anak. Pada dasarnya metode parenting tersebut adalah salah satu cara mendidik anak, yang erat kaitannya dengan konsep pendidikan.
\end{abstract}

Kata Kunci: pembentukan karakter, parenting, ana-anak

\section{Pendahuluan}

Setiap orang tua yang memiliki seorang anak pasti mendambakan anaknya menjadi orang yang berhasil. Berhasil dalam hal apapun, dalam ahlak, pendidikan, karier, dan lain sebagainya. Karena seorang anak akan menjadi penerus untuk generasi selanjutnya. Secara fitrah tidak ada orang tua di dunia ini yang menginginkan anak anaknya menderita, kekurangan, dan tidak bahagia. Sehingga banyak dari orang tua yang dengan segala kekuatannya melakukan berbagai usaha masa depan anaknya. Sikap dan perilaku orang tua sangat berpengaruh terhadap perkembangan seorang anak. Ibnu Khaldun seperti dikutip oleh Hassan menyebutkan bahwa Anak yang di didik dengan paksaan atau kekerasan akan cenderung tumbuh menjadi orang yang suka berbuat kasar, tidak mampu mengontrol emosi, kehilangan kreativitas, dan suka berbohong. Sehingga orang tua dalam mendidik anaknya harus memperhatikan juga keadaan jiwa seorang anak, tidak hanya mendidik anak dengan sesuka hati dan kehendaknya tanpa ada perhatian dan kebijaksanaan kepada anak.

Fakta yang sering ditemui saat ini terkait pola pendidikan anak adalah sebagai berikut :

1. Orang tua selalu mendikte anak 
2. Orang tua membatasi ruang gerak anak untuk bermain.

3. Orang tua banyak yang memperlakukan anak dengan negatif dengan menggunakan kata - kata yang tidak mendidik : nakal, bandel, cengeng dll.

4. Orang tua sering memberikan hukuman baik secara fisik atau verbal.

5. Orang tua tidak mempercayai kemampuan anak

Dari pemaparan diatas, terlihat jelas bahwa cara mendidik anak dengan metode diatas akan berdampak pada psikologis anak ketika dewasa, dominasi orang dewasa disekitar anak yang ternyata tidak selamanya membawa dampak positif yang akhirnya dapat membuka peluang anak untuk berperilaku yang tidak sesuai dengan budaya Indonesia. Dan untuk dapat meminimalkan perilaku negatif anak usia dini maka sangat dianjurkan para orang tua menerapkan sebuah metode yang tepat dalam mendidik anak.

Layaknya sebuah sekolah, pendidikan dalam keluarga harus memiliki kurikulum atau rencana yang jelas, meskipun tidak disusun dalam bentuk draft kurikulum seperti sekolah formal. Orangtua dalam hal ini ibu dan ayah harus memikirkan untuk jangka panjang. Membangun karaktek pada anak tidaklah mudah, jika sejak dini tidak diterapkan nilai-nilai positif. Karna apapun pendidikan yang didapat ketika anak kecil, akan membentuk karakternya hingga dia dewasa.

Menurut Nana Syaodih, penyusunan kurikulum atau rencana pembelajaran yang harus diperhatikan adalah sebagai berikut :

1. Adanya Tujuan

2. Penentuan Isi/Materi

3. Metode

4. Evaluasi
Dari ke empat aspek yang dipaparkan diatas, jika dimasukkan dalam lingkungan pendidikan keluarga, seyogianya para orangtua memiliki tujuan yang baik untuk mendidik anak. Seperti yang sudah penulis jelaskan diatas, orang tua mana yang ingin anak-anaknya gagal, mereka semua ingin menjadikan anaknya berhasil dan sukses. Memiliki karakter yang baik serta berguna bagi nusa dan bangsa juga menjadi kebanggaan keluarga.

Dari tujuan tersebut para orangtua memiliki kewajiban untuk langkah selanjutnya yaitu menentukan materi atau apa saja aspekaspek yang akan diajarkan kepada anak semenjak dini. Hal tersebut harus di diskusikan antara ibu dan ayah agar tidak terjadi perbedaan dalam mendidik anak. Sehingga anak akan merasakan keharmonisan dan kekompakan dalam mendapatkan pendidikan dari orang tuanya.

Dan langkah yang ketiga adalah menerapkan metode atau cara yang seperti apa yang akan digunakan untuk mencapai tujuan diatas, dengan materi-materi yang akan disampaikan ke pada anak yang sudah di diskusikan ayah dan ibu sebelumnya. Metode merupakan langkah yang menentukan tujuan itu berhasil atau tidak, tujuan sebagus apapun, isi materi sebagus apapun, jika menggunakan cara yang kurang tepat, semuanya akan menjadi siasia.

Banyak metode-metode yang dilakukan para orangtua untuk mendidik anaknya, meskipun secara spesifik atau secara terminologi mereka tidak tau apa nama metodenya, yang pasti cara-cara mendidik anak biasanya mereka lakukan mengikuti cara orangtuanya terdahulu ketika mendidik mereka. Para orang tua menjadikan orangtuanya dulu sebagai guru terbaik dalam hidupnya, meskipun seiring berjalannya waktu karena zaman semakin maju, mungkin ada beberapa nilai-nilai atau cara mendidik orang tua yang dulu yang tergeser oleh 
perkembangan zaman sehingga ada modifikasi dalam hal mendidik anak.

Saat ini, munculnya istilah parenting membawa paradigma baru dalam pola pengasuhan anak. Banyak seminar-seminar dilakukan dalam rangka memberikan pengetahuan bagaimana seharusnya mendidik anak. Masyarakat terutama orang tua cukup antusias terhadap hal tersebut karena mereka meyakini bahwa masa depan itu bukan milik mereka melainkan milik anak-anak mereka. Untuk itu para orang tua memiliki kewajiban untuk mendidik anak mereka dengan cara yang tepat, agar memiliki karakter yang baik.

Untuk itu, dalam kesempatan ini penulis tertarik untuk membahas tentang bagaimana membentuk karakter anak usia dini melalui metode parenting ditinjau dalam perspektif pendidikan.

\section{CHARACTER BUILDING}

\section{Pengertian Character Building}

Menurut bahasa, karakter adalah tabiat atau kebiasaan. Sedangkan menurut ahli psikologi, N.K. Singh dan Mr. A.R. Agwan, karakter adalah sebuah sistem keyakinan dan kebiasaan yang mengarahkan tindakan seorang individu. Karena itu, jika pengetahuan mengenai karakter seseorang itu dapat diketahui, maka dapat diketahui pula bagaimana individu tersebut akan bersikap untuk kondisi-kondisi tertentu.

Dilihat dari sudut pengertian, ternyata karakter dan akhlak tidak memiliki perbedaan yang signifikan. Keduanya didefinisikan sebagai suatu tindakan yang terjadi tanpa ada lagi pemikiran lagi karena sudah tertanam dalam pikiran, dan dengan kata lain, keduanya dapat disebut dengan kebiasaan.

Pengertian Charakter Building dalam segi bahasa, Character Building atau membangun karakter terdiri dari 2 suku kata yaitu membangun (to build) dan karakter (character) artinya membangun yang mempunyai sifat memperbaiki, membina, mendirikan. Sedangkan karakter adalah tabiat, watak, akhlak atau budi pekerti yang membedakan seserang dari yang lain. Dalam konteks pendidikan (Modul Diklat LAN RI) pengertian Membangun Karekter (character building) adalah suatu proses atau usaha yang dilakukan untuk membina, memperbaiki dan atau membentuk tabiat, watak, sifat kejiwaan, akhlak (budi pekerti), insan manusia (masyarakat) sehingga menunjukkan perangai dan tingkah laku yang baik berlandaskan nilai-nilai pancasila.

Kilpatrick dan Lickona merupakan pencetus utama pendidikan karakter. Keduanya percaya adanya keberadaan moral absolute yang perlu diajarkan kepada generasi muda agar paham betul mana yang baik dan benar. Lickona (1992) dan Klipatrick (1992) juga Brooks dan Goble tidak sependapat dengan cara pendidikan moral reasoning dan values clarification yang diajarkan dalam pendidikan di Amerika, karena sesungguhnya terdapat nilai moral universal yang bersifat absolut (bukan bersifat relatif) yang bersumber dari agama-agama di dunia yang disebutnya sebagai "the golden rule". Contohnya adalah berbuat jujur, menolong orang, hormat, dan bertanggung jawab (Martianto, 2002).

Pendidikan karakter tidak dapat dipisahkan dari identifikasi karakter yang digunakan sebagai pijakan. Karakter tersebut disebut sebagai karakter dasar. Tanpa karakter dasar, pendidikan karakter tidak akan memiliki tujuan yang pasti.

Pendidikan karakter di indonesia didasarkan pada sembilan pilar karakter dasar. Kararakter dasar menjadi tujuan pendidikan karakter. Kesembilan pilar karakter dasar tersebut adaiah: \{1) cinta kepada Allah dan semesta beserta isinya, (2) tanggung jawab, disiplin dan mandiri, (3) jujur, (4) hormat dan santun, (5) 


\section{2-68 | HARKAT: Media Komunikasi Islam Tentang Gender dan Anak, 12 (1), 2016}

kasih sayang, peduli dan kerja sama, (6) percaya diri, kreatif, kerja keras dan pantang menyerah, (7) keadilan dan kepemimpinan, (8) baik dan rendah hati, serta (9) toleransi, cinta damai dan persatuan. Hal ini berbeda dengan karakter dasar yang dikembangkan di negara lain, serta karakter dasar yang dikembangkan oleh Ari Ginanjar (2007) melalui ESQ-nya. Perbedaan karakter dasar tersebut dapat dilihat di bawah ini:

\section{Heritage Foundation}

a. Cinta kepada Allah

b. Tangung jawab, disiplin, mandiri

c. Jujur

d. Hormat dan santun

e. Kasih sayang, peduli, dan kerja sama

f. Percaya diri, kreatif, kerja keras, dan pantang menyerah

g. Keadilan dan kepemimpinan

h. Baik dan rendah hati

i. Toleransi, cinta damai dan persatuan

Karakter dasar diatas merupakan 9 karakter dasar yang ada di Indonesia dan dijadikan acuan oleh para pendidik untuk membangun karakter tersebut dalam proses pendidikan. Sedangkan di amerika, karakter-karakter dasar yang harus dibangund an dikembangkan adalah sebagai berikut :

\section{Character Counts USA}

a. Dapat dipercaya (trustworthiness)

b. Rasa hormat dan perhatian (respect)

c. Peduli (caring)

d. Jujur (fairness)

e. Tanggung jawab (responsibility)

f. Kewarganegaraan (citizenship

g. Ketulusan (honesty)

h. Berani (courage) i. Tekun (diligence)

j. Integritas

Terdapat 10 karakter dasar yang digagas oleh USA yang sebagian besar hampir sama dengan 9 karakter dasar yang ada di Indonesia. Selain itu, ada juga karakter dasar yang digagas oleh Ary Ginanjar seorang tokoh ESQ, yaitu sebagai berikut:

\section{Ar Ginanjar A}
a. Jujur
b. Tanggung jawab
c. Disiplin
d. Visioner
e. Adil
f. Peduli
g. Kerjasama

Dari pemaparan diatas, memberikan kita informasi mengenai karakter yang bagaimana yang harus diterapkan kepada anak didik kita. Ketiga sumber diatas bisa kita jadikan acuan untuk menumbuhkan karakter pada anak. Pastinya, karakter dasar yang digagas oleh pemerintah Indonesia menjadi acuan dasar kita dalam mendidik anak.

Selanjutnya, bagaimana caranya membangun karakter tersebut, mengingat kita semua mengetahui bahwa membentuk karakter, membangun karakter bukanlah pekerjaan mudah, berikut ini akan dipaparkan mengenai strategi pengembangan karakter.

\section{Strategi Pengembangan Karakter}

Pendidikan karakter menurut Heritage Foundation bertujuan membentuk manusia secara utuh (holistik) yang berkarakter, yaitu mengembangkan aspek fisik emosi, sosial, kreativitas, spiritual dan intelektual siswa secara optimal. Selain itu, juga untuk membentuk manusia yang lifelong learners (pebelajar sejati). 
Strategi yang dapat dilakukan pendidik untuk mengembangkan pendidikan karakter adalah sebagai berikut:

a. Menerapkan metode belajar yang melibatkan partisipasi aktif murid, yaitu metode yang dapat meningkatkan motivasi murid karena seluruh dimensi manusia terlibat secara aktif dengan diberikan materi pelajaran yang kongkret, bermakna, serta relevan dalam kontek kehidupannya (student active learning, contextual learning, inquiry based learning, integrated learning).

b. Menciptakan lingkungan belajar yang kondusif (conducive learning community) sehingga anak dapat belajar dengan efektif di dalam suasana yang memberikan rasa aman, penghargaan. tanpa ancaman, dan memberikan semangat.

c. Memberikan pendidikan karakter secara ekplisit, sistematis, dan berkesinambungan dengan melibatkan aspek knowing the gaod, loving the good, dan acting the good.

d. Metode pengajaran yang memperhatikan keunikan masing-masing anak, yaitu menerapkan kurikulum yang melibatkan juga 9 aspek kecerdasan manusia.

e. Seluruh pendekatan di atas menerapkan prinsip-prinsip

Developmentally Appropriate Practices.

f. Membangun hubungan yang supportive dan penuh perhatian di kelas dan seluruh sekolah. Yang pertama dan terpenting adalah bahwa lingkungan sekolah harus berkarakteristik aman serta saling percaya, hormat, dan perhatian pada kesejahteraan lainnya.

g. Model (contoh) perilaku positif. Bagian terpenting dari penetapan lingkungan yang supportive dan penuh perhatian di kelas adalah teladan perilaku penuh perhatian dan penuh penghargaan dari guru dalam interaksinya dengan siswa.

h. Menciptakan peluang bagi siswa untuk menjadi aktif dan penuh makna termasuk dalam kehidupan di kelas dan sekolah. Sekolah harus menjadi lingkungan yang lebih demokratis sekaligus tempat bagi siswa untuk membuat keputusan dan tindakannya, serta untuk merefleksi atas hasil tindakannya.

i. Mengajarkan keterampilan sosial dan emosional secara esensial. Bagian terpenting dari peningkatan perkembangan positif siswa termasuk pengajaran langsung keterampilan sosial-emosional, seperti mendengarkan ketika orang lain bicara, mengenali dan me manage emosi, menghargai perbedaan, dan menyelesaikan konflik melalui cara lemah lembut yang menghargai kebutuhan (kepentingan) masing-masing.

j. Melibatkan siswa dalam wacana moral. Isu moral adalah esensi pendidikan anak untuk menjadi prososial, moral manusia.

k. Membuat tugas pembelajaran yang penuh makna dan relevan untuk siswa.

Tak ada anak yang terabaikan. Tolak ukur yang sesungguhnya dari kesuksesan sekolah termasuk pendidikan "semua" siswa untuk mewujudkan seluruh potensi mereka dengan membantu mereka mengembangkan bakat khusus dan kemampuan mereka, dan dengan membangkitkan pertumbuhan intelektual, etika, dan emosi mereka.

\section{METODE PARENTING}

Pengertian parenting (pola asuh anak) adalah proses membesarkan dan mendukung perkembangan fisik dan mental yang juga meliputi emosional, sosial, spiritual dan intelektual anak dari bayi hingga dewasa. Tentu 
saja tujuannya untuk menghasilkan generasi muda atau anak-anak yang cerdas, bukan saja cerdas intelektual tetapi juga cerdas emosional dan spiritualnya. Gaya pengasuhan anak pun memiliki peranan penting, anak yang mendapatkan pengasuhan yang baik, biasanya juga memiliki budi pekerti dan sopan santun yang baik dalam masyarakat.

\section{Menurut Ditjen PAUDNI (2011)} Parenting adalah upaya pendidikan yang dilaksanakan oleh keluarga dengan memanfaatkan sumber-sumber yang tersedia dalam keluarga dan lingkungan yang berbentuk kegiatan belajar secara mandiri. Parenting sebagai proses interaksi berkelanjutan antara orang tua dan anak-anak mereka yang meliputi aktivitasaktivitas sebagai berikut: memberi makan (nourishing), memberi petunjuk (guiding), dan melindungi (protecting) anak-anak ketika mereka tumbuh berkembang. Penggunaan kata "parenting" untuk aktivitas-aktivitas orang tua dan anak di sini karena memang sampai saat ini belum ada padanan kata dalam bahasa Indonesia yang tepat.

Orang tua kandung biasanya memiliki peran paling penting dalam parenting, meskipun mungkin peran itu bisa dilakukan oleh kakak, nenek, bibi, paman atau anggota keluarga lainnya, atau bahkan seorang pengasuh atau asisten rumah tangga. Dalam kasus tertentu, seperti anak yatim piatu atau anak-anak yang ditinggalkan oleh orangtuanya menerima pengasuhan dari orang tua asuh. Ada yang diadopsi, diangangkat sebagai anak asuh, atau ditempatkan di panti asuhan.

Dalam proses parenting, gaya orangtua dalam mengasuh anak memiliki banyak perbedaan. Gaya dalam pengasuhan anak itu akan terlihat dalam kehidupan sehari-hari anak, sikap dan perilaku anak merupakan hasil dari sistem pengasuhan yang diterapkan orangtua. Kelas sosial, tingkat kesejahteraan, budaya orangtua dan lingkungan sekitar memiliki pengaruh yang kuat pada metode parenting seperti apa yang diterapkan oleh orang tua. Berikut ini beberapa metode pengasuhan yang biasanya berkembang di masyarakat:

\section{Gaya pengasuhan anak yang Otoriter}

Gaya pengasuhan anak seperti ini sangat kaku karena memiliki segudang aturan ketat yang harus dituruti anak. Gaya parenting ini ada karena sikap orangtua yang otoriter. Mereka memberikan tuntutan yang tingi kepada anak danitu harus dipenuhi, disamping itu mereka sama sekali tidak peka terhadap kebutuhan emosional dan kasih sayang anak. Jika aturan mereka dilanggar, biasanya akan ada hukuman bagi anak. Hukumannya mungkin biasa, tapi secara psikologis anak terluka, karena biasanya tidak ada penjelasan logis bagi anak tentang mengapa ia bersalah, pokoknya "Karena saya bilang begitu, kamu harus mengikuti" atau "Kalau saya bilang salah, ya salah!” Anak-anak yang dibesarkan dalam keluarga atau lingkungan rumah bergaya otoriter, biasanya tampil kurang ceria, selalu murung, dan lebih rentan stres.

\section{Gaya pengasuhan anak yang Permisif}

Gaya pengasuhan anak yang permisif cenderung memanjakan anak. Anak lebih bebas menetukan keinginannya dan mengemukakan pendapatnya. Dalam gaya parenting ini, peraturan orangtua sangat ringan bahkan cenderung memiliki pengawasan yang tidak ketat. Semua keinginan anak hampir semuanya dituruti dengan mudah, yang penting anak tidak mengalami kesulitan dan kesusahan. Anak-anak dari orangtua yang permisif pada umumnya anak-anak bahagia, tetapi mereka memiliki kontrol yang rendah terhadap diri sendiri dan tidak memiliki kemandirian yang baik.

\section{Gaya pengasuhan anak yang Otoritatif}

Mengenai gaya pengasuhan anak otoritatif, banyak psikolog terkenal yang mengatakan gaya ini adalah gaya yang tepat dalam metode 
parenting. Orangtua yang otoritatif lebih mengedepankan logika dan pikiran positif dan jarang menggunakan hukuman. Orang tua lebih bisa membaca perasaan dan kemampuan anak, dan orang tua juga mendukung perkembangan anak dalam banyak hal. Orangtua dan anak menjalin komunikasi yang sangat baik dengan kontrol dan dukungan yang seimbang. Dalam berhubungan dan mejalin kedekatan dengan anak, orang tua otoritatif melibatkan emosi, melibatkan hati. Penelitian menunjukkan bahwa gaya ini lebih menguntungkan daripada gaya otoriter yang terlalu keras atau gaya permisif yang terlalu lembut.

Tahapan pembentukan metode parenting antara lain :

\section{Melakukan identifikasi kebutuhan orang tua;}

Setiap orang tua memiliki kebutuhan dan keinginan yang berbeda-beda terhadap anakanaknya. Ada orang tua yang ingin anak-anaknya bisa cepat membaca, ada orang tua yang ingin anak-anaknya lebih mandiri, ada orang tua yang ingin anak-anaknya pandai menyanyi dan menari, dan lain-lain. Oleh karena itu perlu dilakukan identifikasi kebutuhan orang tua yang beragam tersebut sehingga dapat dikembangkan dan dituangkan dalam kurikulum pendidikan di keluarga.

\section{Membantuk kepanitiaan parenting}

Dalam hal ini, kedua orang tua (Ayah dan Ibu) harus sepakat untuk menerapkan metode parenting dalam mendidik anak. sehingga program parenting yang akan dikembangkan betul-betul dapat menjembatani kebutuhan orang tua.

\section{Membuat job deskripsi masing-masing bagian;}

Dalam hal ini, harus jelas peran seorang ayah dan seorang ibu dalam mendidik anak, sehingga anak akan bisa memutuskan ketika dia meminta sesuatu kepada ayah atau ibunya, karena dari awal peran ayah dan ibu diberitahu baik secara langsung maupun tidak langsung.

\section{Menyusun program;}

Untuk mencapai tujuan yang diharapkan, dalam menerapkan metode parenting sebagai orang tua harus menyusun program-program apa saja yang akan dilaksanakan untuk mengembangkan karakter anak.

\section{Menyusun jadwal kegiatan;}

Disamping menyusun program, juga menyususn jadwal pelaksanaan kegiatan secara rinci dan jelas, waktu dan tempat dan sebagainya.

\section{Mengidentifikasi potensi dan mitra pendukung;}

Dengan pengembangan program parenting perlu dijalin kemitraan, baik itu dengan sekolah tempat anak belajar, ataupun dengan lembagalembaga lain.

\section{Melaksanakan program sesuai dengan agenda;}

Program dan jadwal kegiatan selanjutnya acuan dalam pelaksanaan di lapangan. Apabila terjadi pergeseran agenda kegiatan perlu juga dipersiapkan alternatif pelaksanaannya bila terjadi hambatan di lapangan.

\section{Melakukan evaluasi dan kesepakatan bersama;}

Setiap kegiatan mulai perencaan dilakukan evaluasi agar dapat menghindari kesalahan dan mengetahui kelemahan-kelemahan yang ada. Di samping itu dalam pelaksanaan program parenting ini deperlukan komitmen bersama antara semua komponen yang ada.

Jenis-jenis Program Parenting yang dapat dilaksanakan di dalam keluarga :

\section{Family Gathering}

Family gathering adalah pertemuan keluarga, bisa dnegan keponakan dan sanak 
sodara, hal ini penting dilakukan untuk memperkenalkan anan dengan saudarasaudaranya dan menjalin kekerabatan yang baik.

\section{Foundation Class}

Orangtua harus mulai membiasakan pengenalan-pengenalan karakter pada anak, bisa dengan cara permainan, bercerita, belajar sambil bermain, dsb.

\section{Seminar}

Seminar adalah kegiatan dalam rangka program parenting, yang dapat dilaksanakan dalam bentuk kegiatan seminar. Misalnya dengan menghadiri acara seminar parenting dengan pembicara tokoh atau praktisi yang kompeten, pakar dongeng, psikolog, dan lain-lain.

\section{Hari Konsultasi}

Biasakan orang tua memberi kesempatan kepada anak untuk menceritakan kejadiankejadian yang terjadi pada anak. Baik itu di sekolah maupun di rumah. Hari Konsultasi adalah hari konsultasi untuk orang tua yang harus disediakan atau diluangkan oleh orangtua.

\section{Field Trip}

Field Trip adalah darmawisata, kunjungan wisata, atau kunjungan ke tempat-tempat yang memberikan pengetahuan, Misalnya kunjungan ke museum, kunjungan ke Bandar Udara, Pelabuhan, atau tempat-tempat lain yang sesuai dengan karakter yang akan dikembangkan.

\section{Home Activities}

Home Activities Adalah aktifitas di rumah di bawa ke sekolah, yaitu membawa orang tua untuk menginap di sekolah, bisa dengan melakukan kegiatan perkemahan di lapangan apabila di sekolah tidak mampu menyediakan tempat menginap.

\section{Cooking on The Spot}

Cooking on The Spot Adalah anak-anak belajar masakan, menyajikan makanan dengan bimbingan guru atau bersama dengan orang tua.

\section{Bazar Day}

Jika ada perlombaan-perlombaan atau bazar yang diadakan di sekolah atau event-event tertentu, hendaknya orangtua mengikutsertakan anaknya untuk mampu menampilkan karyakarya terbaiknya.

\section{Mini Zoo}

Mini Zoo adalah kebun binatang mini, yaitu anak-anak diperkenalkan dengan binatangbinatang peliharaan dan diajarkan bagaimana cara merawatnya, agar anak memiliki perasaan kasih dan sayang kepada semua binatang.

\section{Home Education Video}

Home Education Video adalah mendokumentasikan segala aktivitas anak dalam bentuk video agar bisa di evaluasi dan diberikan pelajaran-pelajaran yang berarti.

Kesepuluh program parenting diatas, dapat diterapkan dilingkungan keluarga untuk membentuk karakter yang akan dibangun pada anak-anak kita. Hanya saja yang harus diperhatikan adalah bakat dan minat yanga da dalam diri anak, sehingga cara apapun yang dilakukan sesuai dengan karakteristik anak.

\section{PEMBAHASAN}

Membangun karakter pada anak usia dini memerlukan suatu cara yang tepat. Orang tua sangat berperan penting dalam membangun karakter tersebut. Seperti yang sudah dijelaskan di atas, bahwa berbicara mengenai character building, kita harus memiliki pandangan yang jelas mengenai karakter apa yang akan dibangun serta dikembangkan kepada anak-anak kita. 
Terdapat 9 karakter dasar yang ada di Indonesia, Kesembilan pilar karakter dasar tersebut adalah: $\{1)$ cinta kepada Allah dan semesta beserta isinya, (2) tanggung jawab, disiplin dan mandiri, (3) jujur, (4) hormat dan santun, (5) kasih sayang, peduli dan kerja sama, (6) percaya diri, kreatif, kerja keras dan pantang menyerah, (7) keadilan dan kepemimpinan, (8) baik dan rendah hati, serta (9) toleransi, cinta damai dan persatuan.

Cara membentuk karakter tersebut adalah dengan kebiasan-kebiasan yang positif yang harus dikembangkan oleh para orang tua. Metode parenting yang merupakan cara pengasuhan anak, bisa diterapkan dalam membangun karakter yang ada diatas. Seperti dengan adanya family gathering, mampu menumbuhkan cinta kepada Allah dan kepada sesama umatNya. Karna dalam pertemuan itu anak akan dipertemukan dengan orang lain yang pada dasarnya merupakan orang-orang yang memiliki hubungan darah dengan orangtuanya.

Selain itu, dengan adanya hari konsultasi yang diterapkan dalam metode parenting, membuat anak belajar untuk jujur pada diri sendiri, dan akan berusaha mengungkapkan apapun yang menjadi kendalanya. Dan ini akan menjadikan anak tersebut lebih percaya diri. Untuk itu orang tua juga harus memberi perhatian lebih kepada anak, dan peka terhadap apa yang dialami anak.

Cooking on the Spot, juga cara yang unik dalam mendidik anak, selain anak akan merasa senang diajak dalam aktivitas tersebut, juga akan menumbuhkan kreatifitas anak serta kedisplinan. Bukan hasil masakan nya yang penting, tapi proses yang dilakukan, sehingga akan menumbuhkan karakter anak ketika dewasa nanti.

Bazar Day juga akan menumbuhkan sifat percaya diri pada anak, ketika anak sering di ikut sertakan dalam event-event tertentu, anak tersebut akan tumbuh menjadi anak yang percaya diri, suka tantangan, dan menjadi anak yang bertanggungjawab.

Mini Zoo salah satu cara yang harus juga dilakukan dalam mendidik anak, yaitu memperkenalkan jenis binatang, dan kalo perlu merawat binatang dirumah, ambil orangtua memberi tahu bagaimana cara merawatnya. Hal ini akan menumbuhkan sifat pengasih dan penyayang kepada semua jenis binatang. Anak akan memperlakukan binatang dengan baik, hingga dia dewasa nanti.

Dari sekian banyak cara membangun karakter melalui metode parenting, pada dasarnya semua memiliki tujuan untuk menumbuhkan karakter-karatketer dasar tersebut. Yang menjadi permasalahan dalam keluarga adalah, peran orangtua yang belum mendukung untuk melakaukan itu, misalnya karena keterbatasan pengetahuan dan informasi, sehingga orangtua salah mendidik anak.

Di Era teknologi seperti sekarang ini, sudah seharunya orangtua pro aktif dalam tumbuh kembang anak. Termasuk mulai membiasakn diri dengan menerapkan nilai-nilai karakter yang harus dibangun sejak dini. Semuanya bisa dilakukan dengan cara mengikuti seminar-seminar parenting, searching melalui internet, belajar dari cara mendidik orang tua dahulu, dan lain sebagainya. Banyak cara yang bisa dilakukan, asalkan kita memiliki keinginan yang kuat untuk mendidik anak dengan baik. Karena pada dasarnya, masa depan itu bukan milik kita para orangtua, melainkan milik anakanak kita.

\section{Simpulan}

1. Pendidikan karakter di indonesia didasarkan pada sembilan pilar karakter dasar. Kararakter dasar menjadi tujuan pendidikan karakter. Kesembilan pilar karakter dasar tersebut adaiah: 11$)$ cinta kepada Allah dan semesta beserta isinya, (2) tanggung jawab, 
disiplin dan mandiri, (3) jujur, (4) hormat dan santun, (5) kasih sayang, peduli dan kerja sama, (6) percaya diri, kreatif, kerja keras dan pantang menyerah, (7) keadilan dan kepemimpinan, (8) baik dan rendah hati, serta (9) toleransi, cinta damai dan persatuan.

2. Dalam membangun karakter pada anak usia dini, bisa dilakukan dengan metode parenting, diantaranya family gathering, foundation class, seminar parenting, mini zoo, field trip, hari konsultasi, home activities, bazar day, cooking on the spot, dan home education video. semua cara tersebut bisa dilakukan dengan terlebih dahulu melihat karakteristik anak.

3. Orang tua sangat berperan dalam proses pembentukan karakter anak, untuk itu orangtua harus memiliki pengetahuan yang cukup dalam mendidik anak. Hal tersebut bisa dilakukan dengan cara mengikuti seminar parenting, atau browsing internet, dan cara-cara lain untuk mendapatkan pengetahuan baru dalam mendidik anak. Karena masa depan bukan milik para orangtua, melainkan milik anak-anak kita.

\section{Daftar Pustaka}

Agustian, Ari Ginanjar. 2007. Rahasia Sukses Membangun Kecerdasan Emosi dan Spiritual : ESQ. Jakarta: Arga.

Education. Washington, DC: Character Education Partnership.
Kilpatrick, W. 1992. Why Johny Can't Tell Right From Wrong. New York: Simon \& Schuster, Inc.

Lickona, T. 1992. Educating for Character, How Our Schools Can Teach Respect and Responsibility. Bantam Books, New York.

Lickona, T., Schaps, E., \& Lewis, C. 2003. CEP's Eleven Principles of Effective Character

Martianto, Dwi Hastuti. 2002. Pendidikan Karakter: Paradigma Baru dalam Pembentukan Manusia Berkualitas. Makalah Falsafah Sains. PPS S3 ITB. Bandung.

Pedoman Pendidikan Karakter pada Pendidikan Anak Usia Dini, Direktorat Pembinaan Pendidikan Anak Usia Dini, Ditjen PAUDNI, Kemendiknas. 2011

Pedoman Penyelenggaraan PAUD Berbasis Keluarga, Direktorat Pembinaan Pendidikan

Pendidikan Karakter Anak Usia Dini. Perpustakaankemendiknas go.id.

Puskur, Balitbang Kemdiknas. (2010), Pengembangan Pendidikan Budaya dan Karakter Bangsa: Pedoman Sekolah .Jakarta.

Tim Penyusun Pusat Bahasa. (2001). Kamus Besar Bahasa Indonesia Edisi III Jakarta: Balai Pustaka. 